plate. Great credit will be due to any one who can invent a convenient earthquake safety-lamp, which, it is to be observed, will also constitute a valuable safeguard in ordinary daily life. It is true, so-called safety-lamps are sold in Tơkyō, but they are very ineffective and miserable affairs. The use of metallic oilholders would doubtless greatly les:en the danger.

During his inquiry the writer was shown sixteen lamps that had been broken in the recent earthquake. In one instance the kerosene caught fire, and it was with great difficulty that the residents extinguished it by the aid of wet mats.

\section{MINERALS AT THE AMERICAN} EXHIBITION.

$\mathrm{NE}$ of the most conspicuous features of the American Exhibition is the remarkable collection of minerals brought over and exhibited by Mr. A. E. Foote, of Philadelphia. Many of the specimens, which are extremely fine, have been obtained during collecting-expeditions undertaken by Mr. Foote himself, and several new species and varieties have been made known to science through his indefatigable labours.

The central feature is a hexagonal pavilion covered with mica, and surmounted by a model of a snow crystal. Each side of the pavilion is devoted to a separate mineral region of the North American continent-except the first, which is filled with a collection of gems and ornamental stones. Here are rough and cut specimens of a precious ruby, topaz, opal, williamsite, with examples of malachite and azurite beautifully banded and taking a fine polish.

A lapidary who has had several years' experience in making rock-sections for the British Museum is constantly employed close by.

Minerals from the region near the Pacific coast come next. Wulfenite, a rare species, some the finest specimens ever seen, is here exhibited in large groups of orange-red crystals; also brilliantly red vanadinites and large bright crystals of chessylite or azurite associated with velvet tufts of malachite. All these are from the marvellous country that Humboldt called New Spain. The deep-red garnets from Alaska in their sombre settings of gray mica-schist are especially noteworthy. Among the minerals of the Rocky Mountain region are wonderful crystals of the green Amazon-stone; ore from the famous Bridal Chamber at Lake Valley, New Mexico, so rich that the heat of a match will cause it to melt and fall in drops of nearly pure silver. A space the size of a moderate-sized room produced about $\oint_{100}, 000$. The precious turquoise comes from Los Cerrilloz, New Mexico, where Montezuma got his chalchuhuitls that he valued above gold and silver. The Indians still make long pilgrimages for the sacred stone.

Most striking among the minerals of the Mississippi Valley and Lake region are the blendes and galenas from South. West Missouri, a district that now produces over one-half of all the zinc mined in the world. It was formerly so abundant that farmers built their fences with it. Masses of the lead-ore weighing ten tons were found within 12 feet of the surface. Here Indians formerly procured the lead for their bullets, placing the ore in hollow stumps and building a fire over it.

From Arkansas come fine rock-crystals or hot-spring diamonds, with powerful lodestones, arkansites, and hydrotitanites.

From the Lake Superior region come copper, chlorastrolites, and zonochiorite, a remarkable gem-like mineral.

In the case devoted to the North Atlantic coast region is shodonite, so much used by the Russians in their ornamental work, in fine crystals. The mines at Franklin, N.J., produce also many minerals found nowhere else in the world, such as franklinite, named after the illustrious philosopher; anomolite, in new species recently described by Prof. G. A. König, of the University of Pennsylvania; troostite, jeffersonite, blood-red zincite, \&c., \&c. Cacoclasite, a new species in fine crystals, associated with pink titanite, comes from the same region, as do the remarkable crystals of apatite. These are among the finest specimens ever seen, and associated with them are the brilliant twin-zircons. From the apatite are manufactured hypophosphites to stimulate the appetite, and superphosphates to grow wheat and corn.

The last case devoted to the South Atlantic coast region contains amethysts, sapphires, aquamarines, tantalite, gummite, and uranolite, huge sheets of mica, \&c., \&c.

Next to the wall opposite is a very extensive collection illus- trating the mineralogy of Pennsylvania, which, besides the well-known coal, iron, and other ores that have made the State famous, includes very extraordinary specimens of the rare mineral brucite, from which the medicine, Eppsom salts, may be made; diaspore in fine crystals, corundum for polishing purposes, chromite for producing brilliant yellows, \&c., \&c.

Adjoining, in cases and drawers, are the college and educational collections indispensable for the studies of mineralogy, geology, and chemistry.

The collection of American Geological Surveys and other scientific.works is very extensive, over fifty volumes from Pennsylvania alone being shown. We have devoted so much space to the description of the extensive exhibit made by Mr. A. E. Foote, of Philadelphia, that we can only refer to the minerals shown by Kansas and other States, by the Denver and Rio Grande and C. B. and Q. Railroads, and by various mining companies.

\section{THE FOLK-LORE OF CEYLON BIRDS.}

A CORRESPONDENT of the Ceylon Observer of Colombo referring to the interest excited by Mr. Swainson's new book on " The Folk-Lore and Provincial Names of British Birds," notes some points in the folk-Iore of the birds of Ceylon, obtained largely in conversation with natives. The devil-bird (Syrnium indrani) stands facile princeps for his evil reputation; his cry heard in the neighbourhood of villages is a sure harbinger of death, and the superstitious natives are thrown into great consternation by its demoniac screech. The legend about the bird is as follows :$\mathrm{A}$ jealous and morose husband doubting the fidelity of his wife killed $\mathrm{h} \in \mathrm{r}$ infant son during her absence and had it cooked, and on her return set it before her. She unwittingly partook of it, but soon discovered that it was the body of her child by a finger which she found in the dish. In a frenzy she fied to the forest, and was transformed into a ulania, or devil-bird, whose appalling screams represent the agonized cries of the bereaved mother when she left her husband's house. The hooting of owls in the neighbourhood of houses is believed to bring misfortune on the inmates. The magpie robin, though one of the finest of the song-birds of Ceylon, is similarly tabooed; it has a harsh grating screech towards evening, which is considered ominous. The quack of tbe pond heron flying over a house is a sign of the death of one of the inmates, or of a death in the neighbourhood. If the green pigeon (Nila kobocya) should happen to fly through a house, as it frequently does on account of its rapid and headlong fight, a calamity is impending over that house. Similarly with the crow. But sparrows are believed to bring luck, and are encouraged to build in the neighbourhood of houses, and are daily fed. The fly-catcher bird of Parudise is called " cotton thief," because in ancient times it was a freebooter, and plundered the cloth merchants. As a penalty for its sins it was transformed into a bird and doomed to carry a white cotton attached to its tail. The red wattle lapwing, the alarm bird of sportsmen, has the following legend connected with it :-It is said to represent a woman who committed suicide on finding herself robbed of all her money, amounting to thirty silver pieces, by her son-in-law. The cry of the bird is likened to her lament: "Give the silver, give the silver, my thirty pieces of silver." Its call is heard at all hours, and the stillness of night is broken with startling abruptness by its shrill cry. Another story about it is that when lying in its nest in a paddy field, or a dry spot in a marsh, it lies on its back with its legs in the air, being in continual fear that the heavens will fall and crush its offspring. The story current about the blue-black swallow-tailed fly-catcher (Kazeudu panik'kia) and its mortal enemy, the crow, is that the former, like Prometheus of old, brought down fire from heaven for the benefit of man. The crow, jealous of the honour, dipped its wings in water and shook the drippings over the flame, quenching it. Since that time there has been deadly enmity between the birds. The Indian ground thrush (Pitta coronata) is said to have once possessed the peacock's plumes, but one day when bathing the peacock stole its dress; ever since the Pitta has gone about the jungle crying out for its lost garments. According to another legend, the bird was formerly a prince who was deeply in love with a beautiful princess. His father sent him to travel for some years, and on his return the princess was dead. He still wanders disconsolately about calling her name. It is also said that the peacock, being a bird of sober plumage, borrowed the brilliant 
coat of the Pitta to attend a wedding, and did not return it. The disconsolate Pitta wanders through the jungle calling on the peacock to restore its dress-hence the cry, ayittam, ayittam (my dress, my dress). The cry of the hornbill (Kandetta) is inauspicious and a sure sign of drought. The bird is doomed to suffer intolerable thirst; not being able to drink from any stream or rill, it has the power only to catch the rain-drops in its bill to quench its thirst, and keeps continually crying for rain.

\section{UNIVERSITY AND EDUCATIONAL INTELLIGENCE.}

THE following is the list of candidates successful in the competition for the Whitworth Scholarships, 1887 :- James Whitaker, 21 , engineer student, Burnley, $£ 200$; John Calder, 20, mechanical engineer, Glasgow, $f_{150}$; John Smith, 22, carpenter, Belfast, £I50; Nicholas K. Turnbull, 2I, mechanical engineer, Glasgow, £150; James C. Talbot, 23, engineer, Southampton, f 150 ; Arthur F. Horne, 25, mechanical engineer, Moreton-inMarsh (formerly of Glasgow), £150; Edward J. Duff, 23, engineer, Glasgow, $£ 150$; Robert N.'Blackburn, 20, engineer apprentice, Liverpool, $£ 150$; William Thomson, 20, engineer apprentice, Glasgow, $\delta 150$; William W. F. Pullen, 20, engineer apprentice, Cardiff, $£$ IOO; Edwin Griffith, 20, engineer ap prentice, Glasgow, £roo; Frederick C. Tipler, 23, assistant chemist, Crewe, $f$ Ioo; Thomas H. M. Bonell, 24, analytical chemist, Swindon, $\delta$ Ico ; Richard J. Redding, 22, metallurgist, Plumstead (Woolwich), and Arthur W. Sisson, 25, mechanical draughtsman, Lincoln (equal), £100 each; Arthur H. Abbott, 22, engineer, Great Yarmouth, $£ 100$; George Hough, 23, engineer, Wolverton, $f_{100 ;}$ Harry G. Christ, I9, engineer apprentice, London, $f_{\mathrm{IOO}}$; Harry D. Griffiths, 2I, engineer apprentice, Cardiff, $£ 100 ;$ Denholm Young, 24, engineer apprentice, Edinburgh, $f$ IOo ; Benjamin G. Oxford, 20, engineer apprentice, Liverpool, $f$ roo ; Bernard II. Crookes, 2I, engineer student, Liverpool, f100; George. J. Wells, 23, engineer, London, $£$ roo; John Eustice, 23, engine fitter, Camborne, $£ \mathrm{rco}$; Augustus H. H. Bratt, 24, engineer, Plumstead (Woolwich), £100.

\section{SOCIETIES AND ACADEMIES.}

\section{LONDON.}

Entomological Society, August 3.-Dr. D. Sharp, President, in the chair.-Mr. J. W. Peers and Mr. R. G. Lynam were elected Fellows. - Jonkeer May, the Dutch ConsulGeneral, exhibited a pupa and two imagos of Cecitomyic destructor (Hessian fly) which had been submitted to him by the Agricultural Department.-Mr. W. White exhibited, and made remarks on, a specimen of Philampelus satellitia, Linn., from Florida, with supposed fungoid excrescences from the eyes. Mr. Stainton said he was of opinion that the supposed fungoid growth might be the pollinia of an Orchis. Mr. Poulton ex pressed a similar opinion, and the discussion was continued by Mr. Pascoe and Dr. Sharp.-Mr. White also exhibited a specimen of Catethia alchymista, bred from a pupa collected las autumn on the south coast.-Mr. McLachlan sent for exhibition a number of oak-leaves infested by Phylloxera punctata, Lichtenstein, which he had received from Dr. Maxwel Masters, F.R.S.-Mr. Champion exhibited two rare species of Cunculionidae from the Isle of Wight-viz. one specimen of Baridius analis, and a series of Cathormiocerus socius. He remarked that $C$. maritimus, Rye, had been placed in recent European Catalogues as a synonym of the last-riamed species, but that this was an error. He also exhibited a series of Cicin dela germanica, from Blackgang.-M. A. Wailly exhibited, and made remarks on, a number of living larvæ of Anthercea pernyi, A. mylitta, Telea polyphemus, F'latysamia cecropia, Attacus cynthia, Callosamia promethea, and other silk-producing species. $\mathrm{He}$ also exhibited imagos of the above species, imagos of Antherce yama-mai, and a number of species of Diurni from Sarawak.-Mr. Poulton exhibited crystals of formate of lead obtained by collecting the secretion of the larva of Dicranurc vinula on 283 occasions. The secretion had been mixed with distilled water in which oxide of lead was suspended. The latter dissolved, and the acid of the secretion being in excess the normal formate was produced. Prof, Meldola promised to subject the crystals to combustion, so that their constitution would be proved by the final test.

\section{EDINBURGH.}

Royal Society, July 15.-Special Meeting.-Dr. J. Murray, Vice-President, in the chair.-Prof. Tait submitted a communication by Sir W. Thomson on the stability of the steady motion of a viscous fluid between two paral'el planes. - Sir W. Turner communicated a note by Mr. George Brook on the epiblastic origin of the : egmental duct in teleostean fishes, and birds. Prof. T. R. Fraser read a preliminary note on the chemistry of strophanthin. - Mr. J. J. Coleman described a new diffusimeter and other apparatus for the study of liquid diffusion. - A paper by Mr. Frank E. Beddard was communicated by Prof. Sir W. Turner.-Dr. Murray read a paper on the mean height of the land of the globe. The lower limit he gives is, in round numbers, I 900 feet. The higher limit, which he believes to be more nearly correct, is about 2 roo feet.-Mr. J. T. Cunningham, of the Scottish Marine Station, read a paper on the Chatopoda seden!aria of the Firth of Forth.

July 18.- Sheriff Forbes Irvine, Vice-President, in the chair. - The Chairman intimated the foundation by Dr. Gunning of the Victoria Jubilee Prize, and the conditions of award which have been approved by the donor. The first award of the prize was made to Sir W. Thomson, for a remarkable series of papers on hydrokinetics which he has communicated to the Society. - Mr. W. Durham read the second part of his paper on the laws of solution.-Prof. Tait communicated a paper by Prof. W. Burnside on the partition of energy between the translatory and rotational motions of a set of non-homogeneous elastic spheres. The rotational energy is equal to two times the translational energy.-Dr. H. R. Mill submitted a paper on the salinity, temperature, \&c., of the Firth of Forth.-Prof. Tait communicated a paper by Mr. Albert Campbell on the direct measurement of the Peltier effect. Mr. Campbell has experimented with three pairs of metals. His results agree in every case with Prof. Tait's thermo-electric diagram. The agreement in the case of iron and nickel is of special importance.-Dr. Alex. Scott communicated a paper on vapour-densities at high temperatures. - Prof. Tait read a paper by Dr. G. Plarr on the determination of the curve, on one of the co-ordinate planes, which forms the outer limit of the positions of the point of contact of an ellipsoid which always touches the three planes of reference.-Mr. Buchan read a paper by Mr. A. Rankin on the mean temperatures of the various winds at Ben Nevis Observatory.-Prof. Crum Brown read a paper on ferric ferricyanide as a reagent for detecting traces of reducing gases. This reagent gives a test depending on the production of colour, which is a more delicate test than one which depends on its disappearance.-Prof. Tait communicated some results on the compressibility of water, of mercury, and of glass. The average compressibility of a 20 per cent. aqueous solution of common salt per atmosphere for the first 100 atmospheres is $0^{\circ} 0000316$. It diminishes rapidly with the percentage of salt in solution. The compressibility of common lead glass is 0.0000027 at a temperature of $19^{\circ}$ C.- Prof. Berry Ilaycraft submitted a description of experiments to show the truth of Sir J. Lister's theory of coagulation.-Dr. Murray communicated a paper by Mr. Adam Dickie on the chemical analyses of sea-water from the Clyde sea-area. - The Chairman mentioned the number of papers read during the session, classifying them under various heads. He also read the Jubilee address which had been presented to Her Majesty by the Secretary of State on behalf of the Society.

\section{PARIS.}

Academy of Sciences, August 8.-M. Janssen in the chair. - Observations of the minor planets, made with the great meridian instrument of the Paris Observatory during the first quarter of the year 1887 , communicated by M. Mouchez. The right ascensions and polar distances are given of Leto, Sophrosyne, Undine, Hebe, and nine other minor planets at various dates with Paris mean time, all comparisons being referred to the ephemerides published by the Berlin Jahrbuch, except those of Undine, which are referred to those published in No. 288 of the circulars of the Berlin Jahrbuch. The observations were made by $\mathrm{M}$. O. Callandreau. - Fresh documents on the relations existing between the chemical and mechanical work of the muscular tissue, by M. A. Chauveau, 